\title{
A DEVELOPMENTAL APPROACH TO DEALING WITH YOUNG OFFENDERS: AN IMPERATIVE FOR PROBATION PRACTICE AND POLICY FRAMEWORK
}

\section{Thulane Gxubane}

\section{INTRODUCTION}

The Child Justice Bill (SA Law Commission, B49 of 2002) (CJB) made provision for all children in conflict with the law to be assessed by a probation officer, thus making it possible to divert those children who committed serious offences. The re-drafted $2007 \mathrm{CJB},{ }^{1}$ in contrast, excludes children arrested for serious offences from assessment by a probation officer and therefore denies them the possibility of being diverted from the criminal justice system. This paper challenges the bifurcation of offences, a policy of separating out the minor offences from the serious offences with the intention of being tough on the latter. This is one of the key principles underlying the $2007 \mathrm{CJB}$, which seems to be informed by the general misconception that diversion and restorative justice are inappropriate when dealing with serious youth offences. In contextualising this article, ${ }^{2}$ a brief historical background to the factors that have influenced the reform of child justice in South Africa will be provided. Secondly, the role of a probation officer in relation to policy development, with specific reference to the 2007 CJB, will be examined. Thirdly, the developmental approach to working with young offenders will be explored, so as to create a conceptual framework for the central discourse of this article. Fourthly, the concept of restorative justice as a proposed philosophical and developmental approach to working with young offenders and its appropriateness in dealing with serious youth offences will be investigated. The terms "young" and "child" are used interchangeably, referring to any person less than 18 years of age as stipulated in the Convention on the Rights of the Child (CRC) (1989) and the Constitution of the Republic of South Africa (1996b). Finally, guidelines are offered that can help probation officers to give effect to restorative justice.

\section{THE REFORM OF CHILD JUSTICE IN SOUTH AFRICA}

South Africa did not have a formalised child justice system and was in the final stages of formulating one when this article was written. Children and youth offenders are dealt with under a range of statutes like the Criminal Procedures Act 51 of 1977 (RSA, 1977), the Probation Services Act 116 of 1991 (RSA, 1991), the Probation Services Amendment Act 35 of 2002 (RSA, 2002), the Child Care Act 74 of 1983 (RSA, 1983), the Child Care Amendment Act 96 of 1996 (RSA, 1996a), the Children's Act 38 of 2005 (RSA, 2005) and the Correctional Services Act 111 of 1998 (RSA, 1998).

The case of Neville Snyman illustrates the tragic consequences of the absence of a legislative framework in dealing with children in trouble with the law in South Africa. Neville Snyman

\footnotetext{
${ }^{1}$ The 2007 CJB Cabinet version as introduced in the National Assembly as section 75 Bill. [Online] Available: http: //www.childjustice.org.za/downloads/ChildJusticeBill_2007.pdf

${ }^{2}$ This article is based on a paper presented at the $2008 \mathrm{XV}$ World Congress of the International Society for Criminology in Spain (Barcelona) and was inspired by the author's submissions to the Justice and Constitutional Development Portfolio Committee on behalf of the Department of Social Development, University of Cape Town, during the 2008 public hearings on the re-drafted Child Justice Bill (B49 of 2002).
} 
was a 13-year-old boy who was arrested with friends for breaking into a local shop and stealing sweets and cool drinks, and was subsequently beaten to death by older youth cellmates while awaiting trial for his housebreaking charge. His death in September 1992 led to rigorous advocacy for the reform of the child justice system in South Africa (Skelton, 1999).

South Africa's transformation to democracy within a human rights framework, as well as its commitment and accountability towards international benchmarks for children's rights, particularly the CRC (1989), had a great influence on shifts in policy and legislation in South Africa. Linked to this was a shift in political will, which became conscious of the negative conditions faced by children in prison. Dr Nelson Mandela, as the head of the first democratically elected government in South Africa, was concerned about the huge number of children who were kept in detention for lengthy periods, and about their exposure to different forms of abuse and sometimes even death. As pointed out by Skelton (1999:96), the political will to change this situation was reflected in Mandela's early speech in April 1994, when he addressed Parliament as follows:

The government will, as a matter of urgency, attend to the tragic and complex question of children and juveniles in detention and prison. The basic principle from which we will proceed from now onwards is that we must rescue the children of the nation and ensure that the system of criminal justice must be the very last resort in the case of juvenile offenders.

The South African Law Commission was appointed in 1996 by the then Minister of Justice, Mr Dullah Omar, to investigate the youth justice system as part of the National Plan for Action in guiding legislative and policy shifts in South Africa (SA Law Commission, 1997). On completion of this investigation, the SA Law Commission (1997) recommended a comprehensive transformation of the youth justice system, which would be framed by international instruments and the Constitution of the country. The restorative justice frame of reference was one of the key fundamental principles recommended by the SA Law Commission (2000) in dealing with young people in conflict with the law. This philosophical framework is very much the cornerstone of the CJB.

The CJB was approved by Cabinet in November 2001 for introduction into Parliament in August 2002 as Bill 49 of 2002. Having disappeared from the public eye for more than five years, the CJB was re-redrafted and recently brought back before Parliament on the 5 th and the 6th February 2008 for public hearings.

\section{PROBATION OFFICERS AND POLICY DEVELOPMENT}

Whilst social work has taken different forms and followed different directions over the years of its existence as a profession, social workers should not forget that contributing to the development and modification of social policy is one of the primary purposes of social work. As asserted by Du Bois and Miley (1992:46) "(i)t is critical for social workers to be able to provide public testimony, engage in legislative advocacy and ... [they] must be skilful advocates for social policy development, particularly as it affects oppressed population groups in society". Therefore, since probation officers are social workers, it is imperative for them to contribute to policy development, and particularly to those policies that relate directly to their daily practice. Probation officers can offer a wealth of knowledge and insight gained from their experience in working with young offenders and their families. Sadly, such contributions have not been forthcoming in South Africa. Probation officers, like generic social workers, have 
been and continue to be implementers rather than generators of social policies (Mazibuko, 1996).

By failing to participate in policy development, probation officers are not only leaving it up to policy-makers to define the role of probation officers, but they are also missing a good opportunity to influence other role players and policy makers in the child justice system by advising them how to manage young offenders. For example, in terms of the re-drafted 2007 CJB children who commit serious offences were excluded from being assessed by probation officers and, consequently, excluded from a possibility of diversion. It was submitted to the justice and constitutional development portfolio committee that, while it is clear that diversion may not be appropriate for all cases, the assessment process is nonetheless essential to evaluating the child, the family circumstances of the child, the nature and circumstances surrounding the alleged commission of an offence, its impact on the victim, the attitude of the alleged offender in relation to the offence and any other relevant factors that can guide the court to make an informed decision whether diversion is appropriate or not. Therefore all children who are in conflict with the law must be assessed by a probation officer (Gxubane, 2008).

\section{DEVELOPMENTAL APPROACH TO WORKING WITH YOUNG OFFENDERS}

The occupation of probation is rooted in the value base of the social work profession in South Africa. Probation practitioners provide mainly remedial support services to the courts. Little or no attention is given to the long-term interests of the child offender, the victim and the community. Whilst providing support services for the courts, which are mainly offender oriented, the probation officers should not lose sight of the social and professional imperatives to align their interventions with the national developmental agenda of the country relating to the prevention of crime. Probation officers as social workers have the professional responsibility of translating the constitutional mandate into policy and professional practice.

The mandate of the developmental approach in probation and social work practice is derived from the Constitution of the Republic of South Africa of 1996 and from various other international and regional standard-setting instruments, which were adopted by the South African government (Patel, 2005). A developmental approach to social work practice is defined as "the practical and appropriate application of knowledge, skills and values to enhance the well-being of individuals, families, groups, organisations and communities in their social context" (Patel, 2005:206-207). This approach aims to promote social change through a dual focus on the person and the environment, as well as on the interaction between the two (Patel, 2005). In the child justice system this would entail holistic and multidisciplinary interventions that are not only focused on changing the symptomatic criminal behaviour of the child offender, but also on ascertaining the underlying causal factors and systems that have an impact on the child's social functioning.

The White Paper for Social Welfare (RSA, 1997) and the Inter-Ministerial Committee on Young People at Risk (1998) proposed that restorative justice, diversion programmes, prevention and early intervention programmes should be the key principles to inform criminal justice thinking in managing young offenders in South Africa. This implies a paradigm shift away from the retributive system, which focuses on punishment, towards a restorative justice approach, which promotes accountability and reconciliation. Both the Inter-Ministerial Committee on Young People at Risk (1998) and the White Paper for Social Welfare (RSA, 1997) emphasised restorative justice because this approach seeks to channel young offenders away from the criminal justice system and to provide them with an opportunity to be 
accountable for their unlawful behaviour, encouraging them to make amends to their victims rather than just being punished.

The Child Justice Alliance ${ }^{3}$ has been involved in various rigorous advocacy, research, lobbying and media strategies, aimed at drawing the government's and the public's attention to a need for a formalised child justice system in South Africa. Fatima Chohan (2007:13), the chairperson of parliament's justice and constitutional development committee reportedly said:

(I)t is unlikely that the Bill would be passed by the end of the year (2007)... [T] he committee had sent the Bill back for redrafting so that it could be divided into categories of minor and serious offences... even when the Bill was passed, a lack of capacity and structures could hamper its implementation. A lack of social workers to act as probation officers, as well as a shortage of places of safety for children were some of the constraints that would be faced.

It would therefore seem that a major delay in the enactment of the CJB was not only caused by a lack of human and material resources, as stated in Chohan's speech above, but rather by policy makers' orientation towards punishment, as reflected in the 2007 CJB approach to the bifurcation of child offenders. The anticipated danger of this is that child offenders who are accused of having committed serious offences will follow the same trial and prosecution route as their adult counterparts. If they are found guilty, they are also likely to be given harsh direct imprisonment sentences.

It has been pointed out by many scholars, including Batley and Maepa (2005:16), that "applying harsher punishment to offenders has been shown internationally to have little success in preventing crime". Imprisonment has long-lasting and devastating effects on young offenders and the community in general. In a study that investigated recidivism among young offenders, Gxubane (2006) found that, when young offenders are released back into their communities on completion of their custodial sentences, they are often negatively affected by their institutional experience, and find it very difficult to become reintegrated into society, which leads to recidivism. Depriving a child offender of his or her liberty should be considered as a last resort. When it is considered to be in the best interest of the child, deprivation of his or her liberty should be for the minimum necessary period and should be limited to exceptional cases, without precluding the possibility of the child's early release (RSA, 1996b; United Nations Standard Minimum Rules for the Administration of Juvenile Justice: “The Beijing Rules", 1985).

\section{RESTORATIVE JUSTICE}

A focus on the philosophy underlying restorative justice is very important, because it has implications for its practice. The practice of restorative justice will largely be influenced and shaped by how each person conceptualises it.

Various scholars define restorative justice in different ways, according to the specific aspects of the concept that they want to emphasise. Liebmann (2007) notes, for instance, that some scholars proposed that the term "restorative justice" needs to be replaced with the term

\footnotetext{
3 This is a lobby group and inter-organisational coalition made up of NGOs, CBOs, academic institutions and individuals geared towards campaigning for the Bill and transforming child justice in South Africa. The author attends quarterly meetings of the Child Justice Alliance Driver Group on behalf of the University of Cape Town's Department of Social Development.
} 
"restorative approaches", because "restorative justice" has been used in various other contexts, such as in schools for disciplinary hearings. She argues that the central tenet underlying all definitions of restorative justice is that they all generally point to the restoration of the victim and the community, rather than merely punishing the offender. She states that, in the criminal justice context in its simplest terms, "Restorative Justice aims to restore the well-being of victims, offenders and communities damaged by crime, and to prevent further offending" (Liebmann, 2007:25).

Zehr (2002:54-57) asked the following questions as pointers in evaluating whether a process or programme is restorative in nature or not:

- Does it address harms and causes?

- Is it victim oriented?

- Are offenders encouraged to take responsibility?

- Are all three stakeholder groups involved?

- Is there an opportunity for dialogue and participatory decision-making?

- Is it respectful to all parties?

Skelton and Batley (2006), referring to Zehr's questions, argued that it may not be possible or even desirable for every restorative justice programme or process to address all six questions above, but that it should include at least some of them. Restorative justice has to be conceptualised as an approach, a mindset, or a way of thinking about justice rather than a particular process or programme. Sharpe (2004) proposed that it is becoming important to talk not so much about what is not restorative as to define what it $i s$, and she thus supported a restorative justice continuum framework. In terms of this restorative justice processes and programmes can be placed along the continuum of restorative justice as illustrated below:

\begin{tabular}{|c|c|c|c|c|}
\hline Fully & Mostly & Partially & Potentially & Pseudo- or Non- \\
\hline Restorative & Restorative & Restorative & Restorative & Restorative \\
\hline
\end{tabular}

According to this continuum, some processes will be fully restorative, others will be pseudo- or non-restorative, and yet others may be partially and/or potentially restorative (Sharpe, 2004).

\section{RESTORATIVE JUSTICE AND SERIOUS OFFENCES}

Batley (2005:31) provides a comprehensive response to the question as to whether restorative justice is appropriate in dealing with serious offences. He states that:

Applying restorative justice principles and processes in rape and murder cases does not imply minimizing the seriousness and tragedy of such incidents, nor does it suggest that perpetrators should be let off the hook simply because they have apologized. Serious cases present excellent opportunities for victims to feel that they are heard, and for perpetrators to be confronted with the real consequences of their actions. Specific steps can also be taken to ensure that victims are not dealt with insensitively, as restorative justice seeks to promote the respect and dignity of all concerned, especially those who have been hurt.

In a study conducted in central Johannesburg on victims' views regarding a desirable response to criminals, the results, surprisingly, indicated that the public might be more reasonable than politicians believe when it comes to the treatment of offenders (Leggett, 2005). The study 
showed that victims were not as single-mindedly retributive as many would believe, particularly considering that this area has one of the highest crime rates in South Africa. Although many victims did express a desire for vengeance, they also consistently expressed an interest, across offence types, in telling the offender how they felt. Leggett (2005) therefore concludes that his findings support the belief that victims in South Africa are open to creative and restorative approaches to resolving crime.

In other research that explored challenges and opportunities for restorative justice in the Western Cape from the perspectives of both victims and perpetrators of youth crime, Shearar (2005) found that most victims and perpetrators welcomed the notion of restorative justice as a means of dealing with criminal cases involving young offenders.

Skelton and Batley (2006) argue that the assessment of whether a case is suitable for invoking restorative justice options should not only focus on the seriousness of the offence but also on the circumstances surrounding the offence. Cases in which there is an identifiable victim are all suitable for restorative justice (Skelton \& Batley, 2006). The fact that restorative justice is thus available across the range of criminal justice system processes is also an important factor in understanding that it can be applied to serious offences (Skelton \& Batley, 2006). Even where the offender has served a part or all of his or her prison term, restorative justice can still be part of the resolution.

In research that was conducted by Gantana (2006), exploring the implementation of restorative justice by magistrates, prosecutors and probation officers in sentencing young offenders in the Western Cape, the researcher found that her respondents were familiar with the concept of restorative justice and its value. However, she noticed in the charge sheets that the justice officials still preferred the traditional way of sentencing. She interpreted this to mean that her respondents did not completely believe in the benefits that restorative justice would offer to the parties involved. She concluded that a holistic approach that involves the victim, offender and community, with more interdisciplinary cooperation between different role players, in the actual application of restorative justice to sentencing would be imperative.

\section{GUIDELINES FOR GIVING EFFECT TO RESTORATIVE JUSTICE}

Restorative justice is practised mostly within the diversion framework, although it can also be used as a sentencing option. A probation officer has an important role to play in giving effect to restorative justice through both direct and indirect methods of social work interventions. Restorative justice is often perceived as a lenient approach to dealing with offenders. Because of such misconceptions an essential starting point at a macro-level is to change mindsets. Effectively the probation officer also needs to assume the roles of educator, consultant and advocate and at the same time act a catalyst in helping to eradicate fear, misunderstanding and ignorance about restorative justice. Education and training in restorative justice needs to be conducted across different direct and indirect forms of interventions in the community, with professionals as well as with para-professionals.

At a community level it would involve developing workshops and awareness campaigns in the community, clarifying why the retributive justice system has failed and why a new approach to combating crime is needed, and amplifying the potential benefits of restorative justice. When dealing with professionals, this involves facilitating training workshops for the different professionals, such as social workers, probation officers, justice officials and others involved in applying restorative justice. Similarly, when working with para-professionals, in addition to training them in the policies and principles of restorative justice, at a supervisory level the 
probation officer needs to offer support and guidance with regard to the practical implementation of restorative justice in the field.

At a micro-level this would include mainly direct forms of interventions with the victim, the offender, their families and the community in general. The roles that the probation officer will assume at this level include those of mediator, therapist, advocate, facilitator and coordinator. The 2007 CJB makes provision for the application of restorative justice across different levels of criminal procedure from early intervention in the form of diversion to the final stage as a sentencing option. The Inter-Ministerial Committee on Young People at Risk (1998) proposed an early intervention framework, which states that children in conflict with the law need to be offered the option of diversion in a manner that protects their rights and involves them and their families in decision making.

The 2007 CJB makes provision for children in conflict with the law to be considered for diversion by the presiding officer at a preliminary inquiry, by the prosecutor or by the Director of Public Prosecutions at a pre-trial stage of criminal procedure. An important part of the assessment phase when a child has been arrested is exploring with the family of the child and the victim, where appropriate, about possibilities of diversion. In cases where the child is diverted, the probation officer needs to be aware of various diversion programmes available in the community, so that he or she can refer the child to a specific one that will address the particular needs of that child.

Family group conferencing (FGC) and victim-offender mediation (VOM) place the probation officer in a central role, ranging from planning, convening and facilitating to reporting and making recommendations to the court, based on the outcomes of the FGC. Families of both the victim and the child offender need to be encouraged to participate in the restorative justices processes wherever possible and appropriate. It is therefore vital for the family of the child offender and that of the victim to be willing to participate in these processes. Similarly, where FGC is considered as a sentencing option, the probation officer and the families of both the child in conflict with the law and the victim are central in the process.

\section{CONCLUSION}

This article has looked briefly at the historical background to the reform of child justice in South Africa. A discussion on the developmental approach to working with young offenders was provided to contextualise the paper. The paper has argued for a developmental approach to managing child offenders, because such an approach will not only maximise the opportunities for meaningful interventions that could translate into prevention of crime and recidivism among young offenders, but it will also have long-term benefits for the young offenders, their victims and the country in general. The article also highlighted the importance of the often-neglected but equally important roles of a probation officer, such as research, advocacy and policy development. Employers of probation officers need to embark on a strategic drive to provide resources and incentives that will encourage and enable probation officers to participate in their other equally important roles, such as research, advocacy and policy development. Thereafter, the concept of restorative justice as a proposed philosophical and developmental approach to working with serious offences was discussed in challenging the general misconception that restorative justice is inappropriate in dealing with serious offences. Finally, guidelines were offered that can help probation officers in giving effect to restorative justice. 


\section{REFERENCES}

BATLEY, M. \& MAEPA, J. 2005. Introduction. In: Beyond retribution: prospects for restorative justice in South Africa. ISS Monograph Series No. 111. Pretoria: Institute for Security Studies and Restorative Justice Centre.

BATLEY, M. 2005. Restorative justice in the South African context. In: Beyond retribution: prospects for restorative justice in South Africa. ISS Monograph Series No. 111. Pretoria: Institute for Security Studies and Restorative Justice Centre.

CHOHAN, F. 2007. Five years on, kids in jail wait for justice. Cape Argus, 11 April, 13.

DU BOIS, B. \& MILEY, K.K. 1992. Social work: an empowering profession. Boston: Allyn and Bacon.

GANTANA, K. 2006. The implementation of restorative justice by magistrates, prosecutors and probation officers in sentencing of young offenders at selected district magistrate courts in the Western Cape: Cape Town: University of Cape Town. (M Thesis in Probation \& Correctional Practice)

GXUBANE, T. 2006. An insight into recidivism among awaiting-trial youth offenders and the implications for practice. Social Work/Maatskaplike Werk, 42 (3/4):307-326.

GXUBANE, T. 2008. UCT Department of Social Development submission to the Justice and Constitutional Development Portfolio Committee on the 2007 version of the 2007 CJB 49 of 2002. [Online] Available: http://www.childjustice.org.za/submissions/2008Submissions/ Department\% 20of\% 20Social\% 20Development.pdf [Accessed: 20/05/2008].

INTER-MINISTERIAL COMMITTEE ON YOUNG PEOPLE AT RISK. 1998. Minimum Standards: South African Child and Youth Care System. Pretoria.

LEGGETT, T. 2005. Justice versus retribution: attitudes to punishment in the Eastern Cape. In: ISS Monograph Series No. 45. Pretoria: Institute for Security Studies.

LIEBMANN, M. 2007. Restorative justice: how it works. London and Philadelphia: Jessica Kingsley Publishers.

MAZIBUKO, F. 1996. Social workers and social policy: related functions and skills in practice. Social Work/Maatskaplike Werk, 32(1):148-161.

PATEL, L. 2005. Social welfare and social development in South Africa. Cape Town: Oxford University Press.

RSA (REPUBliC OF SOUTH AFRICA). 1977. Criminal Procedure Act 51 of 1977. Government Gazette, Pretoria: Government Printers.

RSA (REPUBliC OF SOUTH AFRICA). 1983. Child Care Act 74 of 1983. Government Gazette. Pretoria: Government Printer.

RSA (REPUBLIC OF SOUTH AFRICA). 1991. Probation Services Act 116 of 1991. Government Gazette. Pretoria: Government Printers.

RSA (REPUBlC OF SOUTH AFRICA). 1996a. Child Care Amendment Act 96 of 1996. Government Gazette. Pretoria: Government Printer.

RSA (REPUBLIC OF SOUTH AFRICA). 1996b. The Constitution of the Republic of South Africa. Act 108 of 1996. Pretoria: Government Printer. 
RSA (REPUBLIC OF SOUTH AFRICA). 1997. The White Paper for Social Welfare. Pretoria: Government Printer.

RSA (REPUBLIC OF SOUTH AFRICA). 1998. Correctional Services Act 111 of 1998. Government Gazette. Pretoria: Government Printer.

RSA (REPUBLIC OF SOUTH AFRICA). 2002. Probation Services Amendment Act 35 of 2002. Government Gazette. Pretoria: Government Printer.

RSA (REPUBLIC OF SOUTH AFRICA). 2005. Children's Act 38 of 2005. Government Gazette. Pretoria: Government Printer.

SA LAW COMMISSION. 1997. Issue Paper 9 - Juvenile Justice. Pretoria. Government Printer.

SA LAW COMMISSION. 2000. Report on Juvenile Justice. Pretoria. Government Printer.

SA LAW COMMISSION. 2002. Child Justice Bill, B49-2002. Project Committee on Juvenile Justice, Pretoria.

SHARPE, S. 2004. How large should the restorative justice 'tent' be? In: ZEHR, H. \& TOEWS, B. (eds) Critical issues in restorative justice. Monsey, New York: Criminal Justice Press.

SHEARAR, A. 2005. A new approach to child justice?: exploring challenges and opportunities for restorative justice in the Western Cape from the perspectives of victims and perpetrators of youth crime. Cape Town: University of Cape Town. ( $M$ Thesis in Probation \& Correctional Practice)

SKELTON, A. \& BATLEY, M. 2006. Charting progress, mapping the future: restorative justice in South Africa. Pretoria: Restorative Justice Centre and Institute for Security Studies.

SKELTON, A. 1999. Juvenile justice reform: children's rights and responsibilities versus crime control. In: DAVEL, C.J. (ed) Children's rights in a transitional society. Pretoria: Protea Books House.

UNITED NATIONS CONVENTION ON THE RIGHTS OF THE CHILD. 1989.

UNITED NATIONS STANDARD MINIMUM RULES FOR THE ADMINISTRATION OF JUVENILE JUSTICE. (The Beijing Rules) (1985).

ZEHR, H. 2002. The little book of restorative justice. Illinois: Intercourse, PA Good Books.

Mr Thulane Gxubane, Department of Social Development, University of Cape Town, Rondebosch, South Africa. 